\title{
Analgesic and anti-inflammatory activity of the extracts from Cyperus rotundus Linn rhizomes
}

\author{
Manivannan Rajamanickam*, Aeganathan Rajamanickam \\ Department of Chemistry, Government Arts College (Autonomous), Kumbakonam, Tamilnadu, India.
}

\section{ARTICLE INFO}

Article history:

Received on: 01/05/2016

Revised on: 17/06/2016

Accepted on: 27/06/2016

Available online: 26/09/2016

Key words:

Analgesic activity, Anti-

inflammatory activity,

Cyperus rotundus.

\begin{abstract}
The rhizome part of Cyperus rotundus has been shown to contain 5-hydroxymethyl furfural (HMF) (1), methyl ferulate (MF) (2), (E)-ferulaldehyde (FA) (3), and N-trans-feruloyl tyramine (NTF) (4).These known compounds are being reported for the first time from this plant and their structures were determined by physical properties and spectroscopic analyses. The present study was designed to investigate the analgesic and antiinflammatory activities of methanol, chloroform and ethyl acetate extracts of $C$. rotundus. All the extract displayed significant analgesic effect in acetic acid and hot plate pain models in a dose dependent manner. As compared with the other extracts, the ethyl acetate extract $(500 \mathrm{mg} / \mathrm{kg}$ ) was the most effective in the analgesic test similar to standard drugs. In writhing test, ethyl acetate extract $(500 \mathrm{mg} / \mathrm{kg})$ showed significantly, inhibiting pain by $73.44 \%$, similar to aspirin which showed $76.47 \%$ inhibition at the dose of $100 \mathrm{mg} / \mathrm{kg}$ i.p. In hot plate test, ethyl acetate extract $(500 \mathrm{mg} / \mathrm{kg}$ ) produced maximum possible analgesia of $12.72 \pm 1.15 \mathrm{sec}$ at $90 \mathrm{~min}$, whilst morphine sulfate $(5 \mathrm{mg} / \mathrm{kg})$ showed $13.83 \pm 1.15 \mathrm{sec}$. Similarly, carrageenan-induced paw volume was significantly reduced by ethyl acetate extract $(500 \mathrm{mg} / \mathrm{kg})$ at $2.20 \pm 1.184 \mathrm{~h}$ after administration similar to that of diclofenac sodium which showed $2.24 \pm 1.18$ at the dose of $100 \mathrm{mg} / \mathrm{kg}$. The data justify the traditional use of Cyperus rotundus as medicinal plant which has a potential source of bioactive molecules to treat inflammatory diseases.
\end{abstract}

\section{INTRODUCTION}

Cyperus rotundus Linn, sedge of the family Cyperaceae and order cyperales, is widely distributed in the Mediterranean basin areas (Uddin et al., 2006). It grows under a variety of soil conditions like in waste lands; gardens open area etc. but usually prefer a moist and somewhat sandy soil. The tuber part is one of the oldest known medicinal plants used for the treatment of dysmenorrhea and menstrual irregularities (Yu et al., 2004). It is also traditional medicinal plant appearing among the Indian, Chinese and Japanese natural drugs .It is used in the treatment of spasms, stomach disorder and inflammatory diseases (Gupta et al., 1971; Seo et al., 2001; Singh et al., 1970). Other Pharmacological investigations have indicated that it has remarkable

\footnotetext{
* Corresponding Author

E-mail: manickam_mani @yahoo.co.in Mobile: 91-9095715550
}

hypotensive ( $\mathrm{Li}, 1992)$ and antipyretic effects (Vedavathy and Rao 1990). The phytochemical investigation of has revealed the presence of polyphenols, flavonol glycosides, alkaloids, saponins, sesquiterpenoids and essential oils (Nagulendran et al., 2007; Venkatsubramanian et al., 2010). The major compounds isolated from the extracts of $C$. rotundus rhizome are $\alpha$ and $\beta$-cyperone, $\alpha$ and $\beta$-rotunol, $\beta$-pinene, $\beta$-selinene, camphene, cyperene, cyperenone, cyperol, cyperotundone, depoxyguaiene, gammacymene, limonene, linolenic-acid, myristic-acid, oleic-acid, pcymol, pectin, polyphenols, rotundene, rotundenol, rotundone, sugeonol, triterpenes including oleanolic acid and sitosterol, as well as flavonoids, sugars and minerals (Thebtaranonth et al., 1995; Jeong et al., 2000; Sonwa and König 2001).

The present study describes the isolation and structural elucidations of known compounds: 5-hydroxymethyl furfural (1), methyl ferulate (MF) (2), (E)-ferulaldehyde (3), and $\mathrm{N}$-transferuloyltyramine (4) obtained for the first time from the rhizomes of $C$. rotundus. 
The compounds obtained were identified by spectroscopic evidences and by comparison with literature data. To find out the ingredients responsible for the efficiency of this plant, the analgesic and anti-inflammatory activities of different extracts were also studied.

\section{MATERIALS AND METHODS}

\section{Chemistry}

A melting point was determined on a Fisher Scientific melting point apparatus and was uncorrected. UV spectrum was recorded on Ultraviolet spectrophotometer (UV2550, Shimadzu, Japan) and IR spectrum was recorded on FT-IR spectrometer (Perkin Elmer Spectrophotometer, USA) with $\mathrm{KBr}$ tablets from 4000 to $400 \mathrm{~cm}^{-1}$ with $2 \mathrm{~cm}^{-1}$ resolution. NMR experiments was performed on a Bruker AMX 400 instrument (Bruker Company, Faelladen, Switzerland) with standard pulse sequences running of ${ }^{1} \mathrm{H}$ and ${ }^{13} \mathrm{C}$ NMR (400 and $100 \mathrm{MHz}$, respectively). Chemical shift values are in $\delta(\mathrm{ppm})$ with TMS as internal standard material and the coupling constants $(J)$ are in Hz. GC-MS analyzes was performed on a Perkin Elmer Clarus 500 GC-MS systems. The fused-silica HP-5 MS capillary column (30 m - $0.25 \mathrm{~mm}$ ID, the film thickness of $0.25 \mathrm{~mm}$ ) was directly coupled to the MS. Column chromatography (CC) was performed on silica gel 60 as stationary phase (particle size 0.04-0.036 mm, 230-400 mesh, ASTM E. Merck, Germany) and activated by heating at $110^{\circ} \mathrm{C}$ for one hour before use.

\section{Plant material}

Fresh rhizomes of $C$. rotundus growing in wild was randomly collected in the month of December from the river basin of Cauvery at Kumbakonam, Thanjavur District, Tamilnadu (India) and authenticated by Prof. N. Ramakrishnan, (Department of Botany) and voucher specimens (GACBOT-202) was deposited in the Herbarium of Botany Department at Government Arts College (Autonomous), Kumbakonam, Bharathidasan University, India.

\section{Extraction and Isolation}

The dried rhizomes of $C$. rotundus (750 g, wet weight) were extracted with $90 \%$ methanol $(\mathrm{MeOH})(4 \mathrm{X} 500 \mathrm{ml})$ under reflux. The obtained methanol extract was concentrated on a rotatory evaporator under reduced pressure at a temperature of $45^{\circ} \mathrm{C}$ for complete solvent removal, yielding crude methanol extract. The latter was suspended in methanol: $\mathrm{H}_{2} \mathrm{O}(9: 1)$ and was subjected to column chromatography packed with silica gel (column grade) and eluted with chloroform and ethyl acetate respectively. These fractions have collected and the solvent recovered by simple distillation, concentrated in vacuo and left in an ice-chest for a week. The chloroform fraction (37 g) was evaporated in vacuo and chromatographed on a silica gel 60 as stationary phase (particle size 0.04-0.036 mm, 230-400 mesh) with $25 \%$ of acetone in chloroform to yield compound 1 (5.8 g). Further elution with a hexane: ethyl acetate gradient (2:1), yielded compound 2 (3.4 g). The EtOAc fraction was concentrated under vacuum to afford a residue (10.9 g), which was subjected to column chromatography packed with silica gel $(6.0 \times 5.5 \mathrm{~cm}$, 200-300 mesh) and eluted with a gradient of petroleum ether/acetone (10:1) to get compound $3(3.2 \mathrm{~g})$ and further eluting with a gradient of $\mathrm{CHCl}_{3} / \mathrm{MeOH}(10: 1)$ gave compound 4 (5. $\left.6 \mathrm{~g}\right)$.

\section{5-hydroxymethyl furfural (1)}

Dark-yellow liquid; bp $112-114^{\circ} \mathrm{C}$ and or yellow powder; mp $33-34^{\circ} \mathrm{C} ; \quad \mathrm{UV}^{\lambda_{\max }^{\mathrm{MeOH}}}(\log \varepsilon) 220-285 \mathrm{~nm}$; IR $v_{\max }(\mathrm{KBr})$ : 3340, 2920, 1680, 1590, 1450, 1260, $1020 \mathrm{~cm}^{-1} ;{ }^{1}$ HNMR [(400 $\left.\mathrm{MHz}, \mathrm{CDCI}_{3}\right) \delta(\mathrm{ppm}): 9.57(1 \mathrm{H} \mathrm{s}),, 7.23(1 \mathrm{H} \mathrm{d}, \mathrm{J}=3.6 \mathrm{~Hz}$,), 6.52 (1 H d, J =3.6 Hz), $4.71(2 \mathrm{H} \mathrm{s})] ;{ }^{13} \mathrm{C}$ NMR [(100 MHz, $\left.\mathrm{CDCI}_{3}\right) \delta(\mathrm{ppm}): 178.1$ (CHO), 152.0 (C-2), 123.1 (C-3), 110.1 (C-4), 161.9 (C-5),56.8 (C-6).

\section{Methyl ferulate (2)}

Pale yellow gum; $\lambda_{\max }^{\mathrm{MeOH}}(\log \varepsilon) 235,290$ - $320 \mathrm{~nm} ; \mathrm{IR}$ $v_{\max }(\mathrm{KBr}): 3320,2900,2650,2560,1740,1670 \mathrm{~cm}^{-1} ;{ }^{1} \mathrm{H}$ NMR $\left(400 \mathrm{MHz}, \mathrm{CD}_{3} \mathrm{OD}\right) \delta 3.75\left(3 \mathrm{H}, \mathrm{s}, \mathrm{COOCH}_{3}\right), 3.90(3 \mathrm{H}, \mathrm{s}$, $\left.\left.\mathrm{ArOCH}_{3}\right), 6.37(1 \mathrm{H}, \mathrm{d}, \mathrm{J}) 15.9 \mathrm{~Hz}, \mathrm{H}-2^{\prime}\right), 6.82(1 \mathrm{H}, \mathrm{d}, \mathrm{J}) 8.1 \mathrm{~Hz}$, H-5), 7.10 (1H, dd, J ) 2.0, 8.1 Hz, H-6), $7.16(1 \mathrm{H}, \mathrm{d}, \mathrm{J}) 2.0 \mathrm{~Hz}$, $\left.\mathrm{H}-2), 7.59(1 \mathrm{H}, \mathrm{d}, \mathrm{J}) 15.9 \mathrm{~Hz}, \mathrm{H}-1^{\prime}\right) ;{ }^{13} \mathrm{C} \mathrm{NMR}(100 \mathrm{MHz}$, $\left.\mathrm{CD}_{3} \mathrm{OD}\right) \delta 52.3\left(\mathrm{COOCH}_{3}\right), 56.4\left(\mathrm{ArOCH}_{3}\right), 112.1(\mathrm{C}-2), 114.8$ (C-2'), 116.7 (C-5), 124.1 (C-6), 128.2 (C-1), 147.4 (C-1'), 150.2 (C-3), 151.5 (C-4), 170.6 (CO).

\section{(E) - feruldehyde (3)}

Brown oil $\lambda_{\max }^{\mathrm{MeOH}}(\log \varepsilon) 245,310$, and $340 \mathrm{~nm}$; IR $v_{\max }$ $(\mathrm{KBr}):$ 3360, 2880, 2720, 1660, 1610, 1480, 1350, 1230, 1050, 760, $620 \mathrm{~cm}^{-1}$; ${ }^{1} \mathrm{H}-\mathrm{NMR}:\left(400 \mathrm{MHz}, \mathrm{CDCl}_{3}\right): \delta 7.36(1 \mathrm{H}, d, J=$ $2.0 \mathrm{~Hz}, \mathrm{H}-2), 6.82(1 \mathrm{H}, d, J=7.0 \mathrm{~Hz}, \mathrm{H}-5), 7.16(1 \mathrm{H}, d d, J=2.0$ \& $7.0 \mathrm{~Hz}, \mathrm{H}-6), 7.62(1 \mathrm{H}, d, J=16.0 \mathrm{~Hz}, \mathrm{H}-7), 6.60(1 \mathrm{H}, d d, J=$ $16.0 \& 8.0 \mathrm{~Hz}, \mathrm{H}-8), 9.60(1 \mathrm{H}, d, J=8 \mathrm{~Hz}, \mathrm{H}-9), 3.80(3 \mathrm{H}, s$, $\mathrm{OMe}) ;{ }^{13} \mathrm{C}-\mathrm{NMR}\left(100 \mathrm{MHz}, \mathrm{CDCl}_{3}\right): \delta 125.73(\mathrm{C}-1), 110.18(\mathrm{C}-$ 2), 150.15 (C-3), 146.88 (C-4), 115.74 (C-5), 124.10 (C-6), 154.12 (C-7), 115.30 (C-8), 195.16 (C-9), 55.34 (-OMe).

\section{$N$ - trans-feruloyltyramine (4)}

White amorphous solid; mp $90-92{ }^{\circ} \mathrm{C} ; \lambda_{\max }^{\mathrm{MeOH}}(\log \varepsilon)$ 220, 290, 320; IR $v_{\max }(\mathrm{KBr}): 3340,1660,1580,1450,1260,1030$ $\mathrm{cm}^{-1}$; ${ }^{1} \mathrm{H} \mathrm{NMR}\left(400 \mathrm{MHz},\left(\mathrm{CD}_{3}\right)_{2} \mathrm{SO}\right): \delta 3.37(2 \mathrm{H}, \mathrm{t}, \mathrm{J}=6.89 \mathrm{~Hz}$, H-1), 2. 59 (2H, t, $J=7.6 \mathrm{~Hz}, \mathrm{H}-2), 6.98$ (1H, d, H-4, H-8), 6.72 (1H, d, $J=8.63 \mathrm{~Hz}, \mathrm{H}-5, \mathrm{H}-7), 6.48$ (1H, d, $\left.J=15.8 \mathrm{~Hz}, \mathrm{H}-2^{\prime}\right), 7.41$ $\left(1 \mathrm{H}, \mathrm{d}, J=7.2 \mathrm{~Hz}, \mathrm{H}-3^{\prime}\right), 7.16\left(1 \mathrm{H}, \mathrm{d}, J=1.63 \mathrm{~Hz}, \mathrm{H}-5^{\prime}\right), 6.81$ $\left(1 \mathrm{H}, \mathrm{d}, J=8.3 \mathrm{~Hz}, \mathrm{H}-8^{\prime}\right), 7.01\left(1 \mathrm{H}, \mathrm{dd}, J=8.0 \mathrm{~Hz}, \mathrm{H}-9^{\prime}\right), 7.98(1 \mathrm{H}$, $\mathrm{t}, J=5.6 \mathrm{~Hz}, \mathrm{NH}), 3.81(3 \mathrm{H}, \mathrm{s}, 6-\mathrm{OCH} 3), 9.29(1 \mathrm{H}, \mathrm{s}, 7 \mathrm{-OH}), 9.38$ $(1 \mathrm{H}, \mathrm{s}, 6-\mathrm{OH}) ;{ }^{13} \mathrm{C} \mathrm{NMR}\left(100 \mathrm{MHz}, \mathrm{CDCl}_{3}\right): 41.1(\mathrm{C}-1), 34.6(\mathrm{C}-$ 2), 125.9 (C-3), 114.8 (C-4), 130.1 (C-5), 156.2 (C-6), 130.2 (C7), 114.9(C-8), $167.4\left(\mathrm{C}-1^{\prime}\right), 122.0\left(\mathrm{C}-2^{\prime}\right), 148.3\left(\mathrm{C}-3^{\prime}\right), 138.2$ (C- 
4'), $111.0\left(\mathrm{C}-5^{\prime}\right), 148.9\left(\mathrm{C}-6^{\prime}\right), 164.2\left(\mathrm{C}-7^{\prime}\right), 118.1\left(\mathrm{C}-8^{\prime}\right), 123.8$ $\left(\mathrm{C}-9^{\prime}\right), 56.4\left(6^{\prime}-\mathrm{OCH}_{3}\right)$.

\section{Biology}

\section{Animals}

Male albino mice (30 - $40 \mathrm{~g})$ and male albino rats (180 $220 \mathrm{~g}$ ) of Wistar strain were procured from the animal house, Government Arts College (Autonomous), Bharathidasan University, Kumbakonam, Tamilnadu, India. Animals were fasted overnight and were divided into control, standard and different test groups each consisting of six animals. They housed in cages and maintained under standard conditions at $26 \pm 2{ }^{\circ} \mathrm{C}$ and relative humidity $44-56 \%$ and with $10 \mathrm{~h}$ light and $14 \mathrm{~h}$ dark cycles per day for one week before and during the experiments. All animals were fed with the standard rodent pellet diet, and water adlibitum. The experimental protocol was subjected to the scrutiny of the Institutional Animal Ethics Committee (IAEC), Bharathidasan University, Trichirappalli, Tamilnadu, India (Approval No. BDU/IAEC/2011/31/29.03.2011).

\section{Analgesic activity by hot-plate method}

Evaluation of analgesic activity of the plant extract was carried out using hot plate method (Eddy and Leimback 1953). Experimental animals of either sex were randomly selected and divided into eight groups consisting of six mice in each group for control, standard and test groups respectively. The control group was treated with $1 \%$ DMSO at the dose of $10 \mathrm{ml} / \mathrm{kg}$ body weight; test groups were treated at the dose of 250 and $500 \mathrm{mg} / \mathrm{kg}$ and the standard was treated with morphine $(5 \mathrm{mg} / \mathrm{kg}$ ) administered via intraperitoneal (i.p.) route. All animals were lowered onto the surface of a hot plate $\left(55 \pm 0.5^{\circ} \mathrm{C}\right)$ enclosed with cylindrical glass and the time for the animal to jump or lick the forelimb was noted as the reaction time. A cutoff period of 30 seconds was observed to avoid damage to the paw. The observations were made before and after administration of respective drugs at $30 \mathrm{~min}, 60 \mathrm{~min}$, and at the end of $120 \mathrm{~min}$. The reaction time of the test and standard groups were compared with the control.

\section{Acetic acid induced writhing test}

The analgesic activity of the samples was evaluated using acetic acid induced writhing method (Koster et al., 1959). Albino mice (30 - $40 \mathrm{~g}$ ) were divided into eight groups each consisting of six animals. The first group served as control and received $1 \%$ DMSO at the dose of $10 \mathrm{ml} / \mathrm{kg}$ body weight. The second group served as standard (received aspirin at the $100 \mathrm{mg} / \mathrm{kg}$ ) while third and fourth groups served as tests and received plant extracts at the doses of 250 and $500 \mathrm{mg} / \mathrm{kg}$ orally. Acetic acid is administered intraperitoneally to the experimental animals to create pain sensation. Writhing in animals was produced by i.p. administration of $300 \mathrm{mg} / \mathrm{kg}$ acetic acid solution (3\%). The writhing movements were observed and counted for every 30 min after acetic acid administration. The number of writhes of test groups at different dose levels along with standard was compared with the control.
The percent inhibition of writhing count of the treated group was calculated from the mean writhing count of the control group. Percentage inhibition was calculated using the following formula:

$$
\% \text { inhibition }=\left\{\left(\mathrm{W}_{\mathrm{c}}-\mathrm{W}_{\mathrm{t}}\right) \times 100\right\} / \mathrm{Wc}
$$

Where, $\mathrm{W}_{\mathrm{c}}=$ No. of writhes in control group, $\mathrm{W}_{\mathrm{t}}=$ No. of writhes in test group

\section{Anti-inflammatory activity by carrageenan induced rat paw edema}

The anti-inflammatory activity of the test compounds were evaluated in Wistar rats employing the method suggested by Diwan et al., 1989. Extracts of C. rotundus rhizome were administrated to the animals in the test groups at the dose of 250 and $500 \mathrm{mg} / \mathrm{kg}$ by oral route. Animals in the standard group received Diclofenac sodium at the dose of $100 \mathrm{mg} / \mathrm{kg}$, by oral route. Control group animals were received $1 \%$ DMSO at the dose of $10 \mathrm{ml} / \mathrm{kg}$ body weight. The acute inflammation was induced by the sub-plantar administration of $0.1 \mathrm{ml}$ of $1 \%$ carrageenan in the right paw. Paw volume was measured by using digital plethysmometer (Ugo Basile-Italy) before administration of carrageenan and after 1,2, and $3 \mathrm{hrs}$ intervals (Kouadio et al., 2000). The efficacy of different drug was tested on its ability to inhibit paw edema as compared to control group.

Volume of edema $=$ Final Paw Volume - Initial Paw Volume

\section{Statistical analysis}

The experimental results were expressed in multiple comparisons of Mean \pm SEM and was carried out by one-way analysis of variance (ANOVA) followed by Dunnet Multiple Comparisons Test and statistical significance was defined as P < 0.05 .

\section{RESULTS AND DISCUSSION}

\section{Chemistry}

The chloroform and ethyl acetate soluble fractions from the methanol extract of $C$. rotundus rhizome were repeatedly separated by column chromatography. The structure of the isolated compounds was analyzed using UV, IR, ${ }^{1} \mathrm{H}$ - and ${ }^{13} \mathrm{CNMR}$ and MS spectra. Finally, the structure was confirmed by comparison with the reference data, and the compounds were identified as 5hydroxymethyl furfural (HMF) (1), methyl ferulate (MF) (2), (E)ferulaldehyde (3), and N-trans-feruloyl tyramine (NTF) (4) (Figure 1). On the basis of this discovery, the phytochemical isolation of these compounds from the chloroform and ethyl acetate extracts of $C$. rotundus rhizome rhizomes was reported for the first time and the biological activities were evaluated.

Many reports related to 5-HMF have provided significant proof for its potential importance in anticancer activities, applications as nerve medication, protection of the myocardium, treatments of cardiovascular diseases damage to striated muscles and viscera by combining to protein, and decreasing the accumulation of poisons in the body (Fu et al., 2008). 


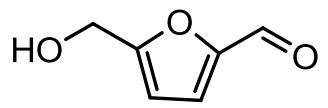

(1)<smiles>COc1cc(/C=C/C=O)ccc1O</smiles>

(3)<smiles>COC(=O)/C=C/c1ccc(O)c(OC)c1</smiles>

(2)<smiles>COc1cc(/C=C/C(=O)NCCc2ccc(O)cc2)ccc1O</smiles>

(4)

Fig. 1: Chemical structure of compounds presence of Cyperus rotundus

Compounds 2 and 3, having similar chemical structure, the methoxy, and hydroxy groups terminate the free radical chain reaction due to their electron donating capacity, and C-C double bonds can provide the attack sites for free radicals. The structural characteristic of ferulic acid and its reduced forms, methyl ferulate (MF) and ferulaldehyde (FA) similar structure, the difference is the one functional group and the presence of the reactive aldehyde group (Kim et al., 1999) and a methoxy group. Ferulic acid and its derivatives have been reported to be effective anti-oxidant, antimicrobial, anti-inflammatory, hepatoprotective, neuroprotective, anti-diabetic and anticarcinogenic compounds (Paiva et al., 2013; Sultana, 2012). N-trans-feruloyl tyramine (NTF), one of the phenylpropanoids, (Dixon and Pavia, 1995) has been reported to show bioactivities such as antimicrobial and anti- HIV activities (Okuyama et al., 1986; Wu et al., 2005). However, analgesic and anti-inflammatory activity of above-isolated compounds have not been well documented.

Compound 1, isolated as dark yellow liquid (b.p. 112$114^{\circ} \mathrm{C}$ ) or yellow powder (m.p $33-34^{\circ} \mathrm{C}$ ), has molecular formula $\mathrm{C}_{6} \mathrm{H}_{6} \mathrm{O}_{3}$ with a molecular ion peak at $\mathrm{m} / \mathrm{z}$ 126.0. Moreover, the fragment ion peaks such as $\mathrm{m} / \mathrm{z} 109.00[\mathrm{M}-\mathrm{OH}]^{+}, 97.00$ (100) $[\mathrm{M}-\mathrm{OHC}]^{+}$, and $81.00[\mathrm{M}-\mathrm{OH}-\mathrm{C}-\mathrm{O}]^{+}$, in the mass spectrum provided more evidence for the final structure elucidation. The UV absorptions at 220 and $285 \mathrm{~nm}$ indicate a furfural chromophore. FT-IR spectra of the HMF give the carbon-carbon stretching vibrations at 1590 and $1450 \mathrm{~cm}^{-1}$ which is attributed to furan ring structure. The absorptions at 1260 and $1020 \mathrm{~cm}^{-1}$ are due to conjugated and unconjugated $\mathrm{C}-\mathrm{O}$ stretching respectively. The absorption at 3340, 2920 and $1690 \mathrm{~cm}^{-1}$ are attributed to $-\mathrm{OH}$, methylene $\left(-\mathrm{CH}_{2}-\right)$ and $\mathrm{C}=\mathrm{O}$ (aldehyde) stretching, respectively. In the ${ }^{1} \mathrm{H}$ NMR spectrum, five signals were observed which can be attributed to one aldehyde proton at $\delta \mathrm{H} 9.57$ (s), two aromatic methine protons at $\delta \mathrm{H} 7.23(\mathrm{~d}, \mathrm{~J}=3.6 \mathrm{~Hz})$ and $6.52(\mathrm{~d}, \mathrm{~J}=3.6 \mathrm{~Hz})$ appeared as an $A B$ spin system, which suggested the characteristics of 2,5-disubstituted furfuran ring. The appearance of the downfield proton signal at $\delta 4.71 \mathrm{ppm}(2 \mathrm{H}, \mathrm{s}, \mathrm{H}-6)$ indicated a methylene group attached to a hydroxyl group. The ${ }^{13} \mathrm{C}$ spectra showed six carbon signals consisting of one aldehyde carbon
(178.1 ppm), one methylene carbon attached to a hydroxyl group (56.8 ppm), two aromatic methines (110.1, and $109.9 \mathrm{ppm})$, and two quaternary carbon atoms (152.0 and $161.9 \mathrm{ppm})$. On the comprehensive spectral analysis, compound $\mathbf{1}$ was elucidated as a known furan derivative, 5-hydroxymethyl-2-furfural (5-HMF) (Hearn, 1976; Miyazawa et al., 2003). Compound 2, was obtained as pale yellow gum. The GC-MS spectrum showed a molecular ion peak at $\mathrm{m} / \mathrm{e} 208$ which is in accordance with the molecular formula of $\mathrm{C}_{11} \mathrm{H}_{12} \mathrm{O}_{4}$. The UV spectrum showed absorption bands at $320 \mathrm{~nm}$ indicating a highly unsaturated chromophoric system and IR spectrum showed absorption bands for the phenolic group $(3380 \mathrm{~cm}), \alpha, \beta$-unsaturated esters $\left(\mathrm{C}=\mathrm{O}, 1690 \mathrm{~cm}^{-1}, \mathrm{C}=\mathrm{C}, 1620\right.$ $\left.\mathrm{cm}^{-1}\right)$ and aromatic moiety $\left(1600-1510 \mathrm{~cm}^{-1}\right)$. The ${ }^{1} \mathrm{H}$ NMR spectral data of $\mathbf{2}$ showed the presence of an (E)-p-methoxy cinnamic acid moiety, as represented by three protons of substituted aromatic rings of which one is doublet of doublet at $\delta$ 7.16 (dd, H-2), with the coupling constant of $\mathrm{J}=2.0 \mathrm{~Hz}$ should be affected by proton of meta position and at $6.82(\mathrm{~d}, \mathrm{H}-5)$ and 7.10 $(1 \mathrm{H}, \mathrm{dd}, \mathrm{H}-6)$, two trans olefinic protons at $\delta 6.35(\mathrm{~d}, \mathrm{H}-\alpha), 7.64$ $(\mathrm{d}, \mathrm{H}-\beta)$, and six protons of two methoxy groups at $\delta 3.75(3 \mathrm{H}, \mathrm{s}$, $\left.\mathrm{COOCH}_{3}\right) ; 3.90\left(3 \mathrm{H}, \mathrm{s}, \mathrm{ArOCH}_{3}\right)$ and hydroxyl group at $\delta \mathrm{H} 6.21$. The ${ }^{13} \mathrm{C}-\mathrm{NMR}$ spectra showed 11 signals, five $\mathrm{sp}^{2}-\mathrm{CH}$, three $\mathrm{sp}^{2}$ quaternary carbon atoms and one due to carbonyl which was confirmed by the resonance at $\delta \mathrm{C} 193.8$ and the last two due to methoxy group. These data agreed well with the data previously reported (Menon et al., 1999; Tawata et al., 1996). Hence, compound 2 was identified as methyl (E)-3-(4-hydroxy-3methoxyphenyl) - prop-2-enoate (methyl ferulate). Compound $\mathbf{3}$ was obtained as a pale yellow liquid; the GC-MS spectrum showed a molecular ion peak at $\mathrm{m} / \mathrm{e} 178.353$ which in accordance with the molecular formula of $\mathrm{C}_{10} \mathrm{H}_{10} \mathrm{O}_{3}$. The UV spectrum displayed absorption band at 245,310 , and $340 \mathrm{~nm}$ which was very similar to ferulic acid (Ishak et al., 1972). IR spectroscopic analysis showed the presence of phenolic group at $3370 \mathrm{~cm}^{-1}$, absorption bands at $1670 \mathrm{~cm}^{-1}$ consistent with $\alpha, \beta$, unsaturated carbonyl group and C-H of aldehyde at $2900 \mathrm{~cm}^{-1}$. The ${ }^{1} \mathrm{H}-\mathrm{NMR}$ spectrum showed the presence of three aromatic protons, each integrated for one proton signal, which appeared at $\delta 7.36(\mathrm{~d}, \mathrm{~J}=2.0 \mathrm{~Hz}), 6.82$ 
$(\mathrm{d}, \mathrm{J}=7.0 \mathrm{~Hz})$, and $7.16(\mathrm{dd}, \mathrm{J}=2.0 \& 7.0 \mathrm{~Hz})$, and was assigned for H-2, H-5 and H-6 of 1,3,4 - trisubstituted aromatic ring. This was further confirmed by ${ }^{13} \mathrm{C}-\mathrm{NMR}$ spectrum, which displayed signals for substituted carbons at $\delta 125.73$ (C-1), 150.15 (C-3), 146.88 (C-4). The downfield shifts of C-3 and C-4 in comparison to $\mathrm{C}-1$ indicated that this carbon bears oxygen functions. The ${ }^{1} \mathrm{H}-$ and ${ }^{13} \mathrm{C}-\mathrm{NMR}$ spectrum displayed the presence of methoxyl group at $\delta 3.81$ and $\delta 55.73 \mathrm{ppm}$, respectively. In addition to these, the ${ }^{1} \mathrm{H}-\mathrm{NMR}$ spectrum displayed a doublet at $\delta 7.62(\mathrm{~J}=16.0 \mathrm{~Hz}, \mathrm{H}-$ 7), a double doublet at $\delta 6.60(\mathrm{~J}=16.0 \& 8.0 \mathrm{~Hz}, \mathrm{H}-8)$, and a doublet at $\delta 9.60(\mathrm{~J}=8 \mathrm{~Hz}, \mathrm{H}-9)$, each for one proton that indicated the presence of olefinic double bond substituted with aldehyde group $(-\mathrm{CH}=\mathrm{CH}-\mathrm{CHO})$. The large coupling constant showed the trans configuration of the double bond. The ${ }^{13} \mathrm{C}-\mathrm{NMR}$ showed 10 signals, including carbonyl which was confirmed by the resonance at $\delta \mathrm{C} 193.8$ and one at 147.0 due to methoxy group. According to the above data compound $\mathbf{3}$ was characterized as (E)ferulaldehyde; ((E) - 4 - hydroxy - 3 - methoxy cinnamaldehyde) by comparison with the literature (Barakat et al., 1987; Kelleys $e t$ al., 1976).

Compound 4 was obtained as colorless crystals. The mass spectrum showed molecular ion peak at $\mathrm{m} / \mathrm{z} 314[\mathrm{M}+\mathrm{H}]+$, consistent with $\mathrm{C}_{18} \mathrm{H}_{19} \mathrm{O}_{4} \mathrm{~N}$. The UV spectrum had three kinds of the band as $\lambda \max (\mathrm{MeOH}): 225,292$, and $320 \mathrm{~nm}$, indicating a highly conjugated system. The IR spectrum of compound 4 showed a large absorption band at $3340 \mathrm{~cm}^{-1}$ (N-H bending) and at $1660 \mathrm{~cm}^{-1}(\mathrm{C}=\mathrm{O}$ stretch $)$ suggesting an amide function. The aromatic skeleton was evidenced by the absorptions between 15800 and $1450 \mathrm{~cm}^{-1}$. The ${ }^{1} \mathrm{H}$ NMR spectrum revealed an aromatic $\mathrm{ABX}$ system in the ferulic acid moiety: $\delta 7.16(1 \mathrm{H}, \mathrm{d}, \mathrm{J}=1.63 \mathrm{~Hz})$, $6.81(1 \mathrm{H}, \mathrm{d}, \mathrm{J}=8.3 \mathrm{~Hz}), 7.01(1 \mathrm{H}, \mathrm{dd}, \mathrm{J}=8.0 \mathrm{~Hz})$ assigned $\mathrm{H}^{-5} 5^{\prime}, \mathrm{H}-$ $8^{\prime}$ and $\mathrm{H}^{-} 9^{\prime}$ respectively and a typical $\mathrm{AA}^{\prime} \mathrm{BB}^{\prime}$ system in the tyramine moiety: $\delta 6.98(1 \mathrm{H}, \mathrm{d}, \mathrm{J}=8.6 \mathrm{~Hz}), 6.72(1 \mathrm{H}, \mathrm{d}, \mathrm{J}=8.6$ $\mathrm{Hz}$ ) assigned $\mathrm{H}-4, \mathrm{H}-8$ and $\mathrm{H}-5, \mathrm{H}-7$ respectively. Furthermore, two triplets integrated for two protons are indicating an ethylic chain at $\delta 3.37(\mathrm{H}-1)$ and $2.59(\mathrm{H}-2)$ and olefinic trans protons appear as two doublets at $\delta 6.48\left(1 \mathrm{H}, \mathrm{d}, \mathrm{J}=15.8 \mathrm{~Hz}, \mathrm{H}-2^{\prime}\right), 7.41$ $\left(1 \mathrm{H}, \mathrm{d}, \mathrm{J}=7.2 \mathrm{~Hz}, \mathrm{H}-3^{\prime}\right)$. In addition, one methoxy group resonating at $\delta 3.81$ is also present. ${ }^{13} \mathrm{C}$ NMR experiment for compound 4 showed 18 carbon resonance signals corresponding two methylene, nine methines, six quaternary carbons, one carbonyl signal and one methoxyl group at $\delta 56.4$. It could be deduced as an amide since the compound showed the negative reaction with ninhydrin but positive after hydrolysis with hydrochloric acid, in addition to the signal appearing at $\delta 167.4$ (s) in the ${ }^{13} \mathrm{C}$ NMR spectrum confirmed the previous fact. These data were in agreement with those reported for the N-trans-feruloyl tyramine (4) (Dellagreca et al., 2009; Sarker et al., 2000).

\section{Biology \\ Analgesic activity}

Pain and inflammation are associated with pathology of various clinical conditions like arthritis, cancer, and vascular diseases (Weitzmann et al., 1990). Hot-plate test is a widely used model for neurologic pain, and centrally acting analgesic agents can increase reaction time in hot-plate test through their action at the spinal cord level (Wigdor and Wilcox 1987). Morphine sulphate used as the standard in this study, acts through binding with opioid receptors $(\mu, \delta$ and $\kappa)$ present in presynaptic and postsynaptic membrane. The reaction time following the oral administration of different doses of plant extracts and standard drug were presented in Table 1. At 90 minutes, the maximum reaction time of two different doses $(250$ and $500 \mathrm{mg} / \mathrm{kg}$ body weight) was $6.42 \pm 1.11 \& 8.60 \pm 1.00$ for methanol extract and $8.89 \pm 1.12 \& 10.67 \pm 1.10$ for chloroform extract of $C$. rotundus respectively. In ethyl acetate extract of two different doses (250 and $500 \mathrm{mg} / \mathrm{kg}$ body weight) the maximum reaction time was $10.34 \pm 1.14 \& 12.72 \pm 1.15 \mathrm{sec}$ respectively, while morphine showed the maximum reaction time of $13.83 \pm 1.15 \mathrm{sec}$ at $90 \mathrm{~min}$ at the dose of $5 \mathrm{mg} / \mathrm{kg}$ (Table 1). The results indicated that the extract significantly $(\mathrm{p}<0.001)$ raised pain threshold as compared to control and the activity was persistent throughout the entire observation period. The result of hot plate test indicates that the extract also possesses the ability to reduce centrally mediated pain. Acetic acid induced abdominal contraction method has been used to evaluate peripherally acting analgesics. In acetic acid induced method pain is generated indirectly via endogenous mediators like prostaglandin, which stimulates peripheral nociceptive neurons. These neuronal fibers are sensitive to both narcotics and nonsteroidal anti-inflammatory drugs (Colier et al., 1968). The acetic acid-induced writhing has been associated with increased level of PGE2 and PGF2 $\alpha$ in peritoneal fluids as well as lipoxygenase products (Derardt et al., 1980). The increase in prostaglandin levels within the peritoneal cavity then enhances inflammatory pain by increasing capillary permeability (Zakaria and Abdul Gani 2008). The plant extract showed positive results for alkaloids and it is well-known that many alkaloids including caffeine, cocaine, cathinone, nicotine, and yohimbine, possess central stimulant effect (Davis et al., 2003). Therefore, the identified polyphenols and alkaloids might contribute in the observed central stimulant effect of $C$. rotundus extract. The significant pain reduction of (Table 2) both the plant extracts might be due to the presence of analgesic principles acting with the prostaglandin pathways. In this test, after oral administration of methanol extract at doses of ( 250 and $500 \mathrm{mg} / \mathrm{kg}$ body weight), the percent inhibition was 45.73 and $55.38 \%$ respectively. On the other hand chloroform and ethyl acetate extract showed maximum inhibition of the writhing such as $58.64 \& 66.17 \%$ and $64.5 \&$ $73.44 \%$ whereas the reference drug aspirin displayed $76.47 \%$ inhibition at the dose of $100 \mathrm{mg} / \mathrm{kg}$ as compared to the control, and the results were statistically significant $(\mathrm{p}<0.001)$. The analgesic effect of the plants in both models suggests that they have been acting through a central and peripheral mechanism (Sabina et al., 2009). It was found that the observed analgesic activity in $C$. rotundus was demonstrated by the active constituents, isolated from the plant extract through a peripherally acting mechanism similar to the non-steroidal anti-inflammatory agents. 
Table 1: Effect of C. rotundus in hot-plate test in mice.

\begin{tabular}{|c|c|c|c|c|}
\hline \multirow{2}{*}{ Treatment } & \multicolumn{4}{|c|}{ Reaction time (in sec) $(\mathrm{M} \pm \mathrm{SD})$} \\
\hline & $0 \mathrm{~min}$ & $30 \mathrm{~min}$ & $60 \mathrm{~min}$ & $90 \mathrm{~min}$ \\
\hline Control (1\% DMSO) & $4.33 \pm 0.55$ & $4.37 \pm 0.58$ & $4.49 \pm 0.50$ & $4.62 \pm 0.60$ \\
\hline Standard (Morphine Sulphate $+5 \mathrm{mg} / \mathrm{kg}$ ) & $4.67 \pm 0.80$ & $8.64 \pm 0.50$ & $11.02 \pm 1.00$ & $13.83 \pm 1.15$ \\
\hline $\begin{array}{r}\mathrm{MeOH} \text { extract } 250 \mathrm{mg} / \mathrm{kg} \\
500 \mathrm{mg} / \mathrm{kg}\end{array}$ & $\begin{array}{l}4.60 \pm 1.10 \\
5.00 \pm 1.00\end{array}$ & $\begin{array}{l}4.92 \pm 1.07 \\
5.33 \pm 0.58\end{array}$ & $\begin{array}{l}5.23 \pm 1.08 \\
6.33 \pm 1.15\end{array}$ & $\begin{array}{l}6.42 \pm 1.11 \\
8.60 \pm 1.00\end{array}$ \\
\hline $\begin{aligned} \mathrm{CHCl}_{3} \text { extract } 250 \mathrm{mg} / \mathrm{kg} \\
500 \mathrm{mg} / \mathrm{kg}\end{aligned}$ & $\begin{array}{l}4.66 \pm 1.12 \\
4.65 \pm 1.15\end{array}$ & $\begin{array}{l}6.18 \pm 0.56 \\
6.33 \pm 0.45\end{array}$ & $\begin{array}{l}7.01 \pm 1.13 \\
8.33 \pm 1.05\end{array}$ & $\begin{array}{c}8.89 \pm 1.12 \\
10.67 \pm 1.10\end{array}$ \\
\hline $\begin{array}{r}\text { EtOAc extract } 250 \mathrm{mg} / \mathrm{kg} \\
500 \mathrm{mg} / \mathrm{kg}\end{array}$ & $\begin{array}{l}4.69 \pm 0.15 \\
4.58 \pm 0.50\end{array}$ & $\begin{array}{l}6.66 \pm 0.75 \\
7.33 \pm 0.70\end{array}$ & $\begin{array}{l}8.18 \pm 1.15 \\
9.67 \pm 1.03\end{array}$ & $\begin{array}{l}10.34 \pm 1.14 \\
12.72 \pm 1.15\end{array}$ \\
\hline
\end{tabular}

Data expressed as Mean \pm SEM, $n=6$ in each group done by one way ANOVA followed by Dennett's test.

Table 2: Effect of C. rotundus on acetic acid induced writhing in mice.

\begin{tabular}{|c|c|c|c|}
\hline Treatment $(n=6)$ & Dose (mg/kg) & $\begin{array}{l}\text { No. of writhes } \\
\text { (Per 30 Min) }\end{array}$ & $\%$ inhibition \\
\hline Control (1\% DMSO) & $10 \mathrm{~mL} / \mathrm{Kg}$ & $34.00 \pm 0.46$ & - \\
\hline Aspirin & $100 \mathrm{mg} / \mathrm{kg}$ & $8.00 \pm 0.28$ & 76.47 \\
\hline $\mathrm{MeOH}$ extract & $\begin{array}{l}250 \mathrm{mg} / \mathrm{kg} \\
500 \mathrm{mg} / \mathrm{kg}\end{array}$ & $\begin{array}{l}18.45 \pm 0.46 \\
15.17 \pm 0.43\end{array}$ & $\begin{array}{l}45.73 \\
5538\end{array}$ \\
\hline $\mathrm{CHCl}_{3}$ extract & $\begin{array}{l}250 \mathrm{mg} / \mathrm{kg} \\
500 \mathrm{mg} / \mathrm{kg}\end{array}$ & $\begin{array}{l}14.06 \pm 0.25 \\
11.50 \pm 0.26\end{array}$ & $\begin{array}{l}58.64 \\
66.17 \\
\end{array}$ \\
\hline EtOAc extract & $\begin{array}{l}250 \mathrm{mg} / \mathrm{kg} \\
500 \mathrm{mg} / \mathrm{kg}\end{array}$ & $\begin{array}{c}12.07 \pm 0.27 \\
9.03 \pm 0.29\end{array}$ & $\begin{array}{c}64 . .5 \\
73.44\end{array}$ \\
\hline
\end{tabular}

Data expressed as Mean \pm SEM, $n=6$ in each group by one way ANOVA followed by Dennett's test.

Table 3: Determination of paw volume of rats for $C$. rotundus extracts.

\begin{tabular}{|c|c|c|c|c|c|}
\hline \multirow{2}{*}{ Groups } & \multirow{2}{*}{ Initial paw volume } & \multicolumn{4}{|c|}{ Paw volume at different time interval (in $\mathrm{ml}$ ) } \\
\hline & & 1h & $2 \mathbf{h}$ & 3h & $4 h$ \\
\hline Control (1\% DMSO) & $1.86 \pm 1.15$ & $1.92 \pm 1.14$ & $1.98 \pm 1.17$ & $1.99 \pm 1.14$ & $1.98 \pm 1.16$ \\
\hline Diclofenac Sodium (100 mg/kg) & $1.86 \pm 1.22$ & $1.98 \pm 1.23$ & $2.16 \pm 1.22$ & $2.32 \pm 1.25$ & $2.24 \pm 1.18$ \\
\hline Methanol extract $(250 \mathrm{mg} / \mathrm{kg})$ & $1.88 \pm 1.19$ & $1.94 \pm 1.22$ & $2.03 \pm 1.24$ & $2.14 \pm 1.28$ & $2.03 \pm 1.14$ \\
\hline$(500 \mathrm{mg} / \mathrm{kg})$ & $1.87 \pm 1.15$ & $1.97 \pm 1.24$ & $2.06 \pm 1.28$ & $2.18 \pm 1.26$ & $2.09 \pm 1.16$ \\
\hline Chloroform extract $(250 \mathrm{mg} / \mathrm{kg})$ & $1.87 \pm 1.20$ & $1.96 \pm 1.26$ & $2.08 \pm 1.26$ & $2.19 \pm 1.24$ & $2.11 \pm 1.19$ \\
\hline$(500 \mathrm{mg} / \mathrm{kg})$ & $1.88 \pm 1.23$ & $1.97 \pm 1.25$ & $2.11 \pm 1.23$ & $2.24 \pm 1.20$ & $2.15 \pm 1.15$ \\
\hline Ethyl acetate extract $(250 \mathrm{mg} / \mathrm{kg})$ & $1.87 \pm 1.24$ & $1.99 \pm 1.24$ & $2.13 \pm 1.24$ & $2.27 \pm 1.26$ & $2.16 \pm 1.16$ \\
\hline$(500 \mathrm{mg} / \mathrm{kg})$ & $1.86 \pm 1.24$ & $1.98 \pm 1.24$ & $2.15 \pm 1.22$ & $2.30 \pm 1.25$ & $2.20 \pm 1.18$ \\
\hline
\end{tabular}

Data expressed as Mean \pm SEM, $n=6$ in each group by one way ANOVA followed by Dennett's test.

\section{Anti-inflammatory activity}

The anti-inflammatory activity of ethyl acetate, chloroform and methanol extract of $C$. rotundus was determined in carrageen induced paw edema of rats and found to be significant compared to diclofenac sodium used as standard (Table 3). Carrageenan-induced paw edema was tested on male albino rats (weighing $180-220 \mathrm{~g}$ ) in suitable experimental animal model for evaluation of anti- edematous effect on natural products (Winter et al., 1962). As shown in Table 3, the rats were divided into eight groups (six animals each) served as control and tested animals. Preferably, two groups are used as control and standard. Acute inflammation was produced by subplantar injection of $0.1 \mathrm{~mL}$ of $1 \%$ suspension of carrageenan in normal saline in the left hind paw of the rats, one hr after the oral administration of the drugs. The paw volume was measured plethysmometrically (Ugo Basile, Italy) at $0 \mathrm{hr}$ and $3 \mathrm{hr}$ after carrageenan injection. All tested groups decreased the thickness of edema of the hind paw compared to the control group. The decrease in the paw volume in the group of animals treated with $C$. rotundus methanolic extract $500 \mathrm{mg}$ was $2.09 \pm 1.16$ and for the chloroform extract $500 \mathrm{mg} / \mathrm{kg}$ was
$2.15 \pm 1.15$ and ethyl acetate $500 \mathrm{mg} / \mathrm{kg}$ was $2.20 \pm 1.18$ at $4 \mathrm{~h}$. The paw volume was compared with that of standard diclofenac sodium $100 \mathrm{mg} / \mathrm{kg}$ and showed percentage paw volume decrease of $2.24 \pm 1.18$. The ethyl acetate extract exhibited maximum activity in comparison with chloroform and methanol extracts. It can be seen that group VI \& VIII showed pronounced antiinflammatory effects after three hours of injection. This effect may be due to phenolic derivatives and alkaloid composition in the plant extracts.

\section{CONCLUSION}

The present study has demonstrated that rhizome part of Cyperus rotundus has been shown to contain 5-hydroxymethyl furfural, methyl ferulate, (E)-ferulaldehyde, and N-trans-feruloyl tyramine and are being reported for the first time. Bioactive substances from this plant can, therefore, employed to develop drugs for the treatment of various inflammatory diseases. The chloroform and ethyl acetate extracts showed pronounced antiinflammatory effects after three hours of injection. The data 
support the folk traditional use of Cyperus rotundus to treat inflammatory diseases that are associated with pain.

\section{Financial support and sponsorship: Nil. \\ Conflict of Interests: There are no conflicts of interest.}

\section{REFERENCES}

Barakat HH, Nawwar, MAM, Buddrus, J, Linscheid M, Niloticol, a phenolic glyceride and two phenolic aldehydes from the roots of Tamarix nilotica, Phytochemistry, 1987; 26 (6): 1837-1838.

Colier HO, Dinneen LC, Johnson CA, Schneider C. The abdominal constriction response and its suppression by analgesic drugs in mouse. Pharmacology, 1968; 32: 295-310.

Davis JM, Zhao Z, Stock HS, Mehl KA, Buggy J, Hand GA. Central nervous system effects of caffeine and adenosine on fatigue. American Journal of Physiology - Regulatory, Integrative and Comparative Physiology, 2003; 284: 399-404.

Dellagreca M, Cutillo F, Abrosca B, Fiorentino A, Pacifico S, Zarrelli A. Antioxidant and radical scavenging properties of Malva sylvestris. Natural Product Communication, 2009; 4: 893-896.

Derardt R, Jougney S, Delevalccee F, Falhout M. Release of prostaglandins $\mathrm{E}$ and $\mathrm{F}$ in an algogenic reaction and its inhibition. European Journal of Pharmacology, 1980; 51: 17-24.

Diwan PV, Karwande I, Margaret I, Sattur PB. Pharmacology and biochemical evaluation of Tridax procumbens on inflammation. Indian Journal Pharmacology, 1989; 21: 1-7.

Dixon RA, Pavia NL. Stress-induced phenylpropanoids metabolism. Plant Cell, 1995; 7, 1085 - 1097.

Eddy NB, Leimback D. "Synthetic analgesic. II. Dithienyl butenylanddithienyl butyl amines", Journal of Pharmacology Experimental Therapy, 1953; 107: 385-393.

$\mathrm{Fu}$ ZQ, Wang MY, Cai BC. Discussion of 5hydroxymethylfurfural (5-HMF) in "Chinese Native Medicine Research Presents." Zhongguo Zhong Yao Za Zhi 2008.26: 3.

Gupta MB, Palit TK, Singh N, Bhargava KP. Pharmacological studies to isolate the active constituents from Cyperus rotundus possessing anti-inflammatory, anti-pyretic and analgesic activities. Indian Journal of Medicinal Research, 1971; 59: 76-82.

Hearn MTW. Carbon-13 chemical shifts in some substituted furans and thiophens, Australian Journal of Chemistry, 29, 107-113 (1976).

Ishak, MS, Sissi, HI, Nawwar, MAM, and Sherbieny, AEA. Tannins and polyphenolic of the galls of Tamarix aphylla. I \& II. Planta Medica, 1972; 21: 246-253 and 374-383.

Jeong SJ, Miyamoto T, Inagaki M, Kim YC, Higuchi R. "Rotundines A-C, three novel sesquiterpene alkaloids from Cyperus rotundus". Journal of Natural Products, 2000; 63, 673-675.

Kelleys, CJ, Harruff, RC, and Carmach, M. The polyphenolic acids of Lithosperrmum ruderale. II: Carbon-13 NMR. Journal of Organic Chemistry, 1976; 41: 449-455.

Kim NY, Pae HO, Ko YS, Yoo JC, Choi BM, Jun CD, Chung HT, Inagaki M, Higuchi R, Kim YC. In vitro inducible nitric oxide synthesis inhibitory active constituents from Fraxinus rhynchophylla. Planta Medicine, 1999; 65: 656-658.

Koster R, Anderson M, De Beer EJ. Acetic acid for analgesics screening. Federation Proceeding, 1959; 18: 412-417.

Kouadio F, Kanko C, Juge M, Grimaud N, Jean A, Guessan YT, Petit JY. Analgesic and anti-inflammatory activities of an extract from Parkia biglobosa used in traditional medicine in the Ivory Coast. Phytotherapy Research, 2000; 14: 635-637.

Li GX. Pharmacology, Toxicity and Clinic of Traditional Chinese Medicine. Tianjin: Tianjin Science and Technique Translation Publishing House, 1992; 194-195.

Menon SR, Patel VK, Mitscher LA, Shih P, Pillai SP, Shankel DM. Structure-antimutagenic activity relationship study of plicatin B12. Journal of Natural Products, 1999, 62: 102-106.
Miyazawa M, Anzai J, Fujioka J, Isikawa Y. Insecticidal compounds against Drosophila melanogaster from Cornus officinalis Sieb. Natural Product Research, 2003; 17: 337-9.

Nagulendran KR, Velavan S, Mahesh R, Begum VH. E-journal of Chemistry 2007; 4(3): 440-449.

Okuyama T, Shibata S, Hoson M, Kawada T, Osada H, Noguchi T, Planta Medica, 1986; 52, 171- 175.

Paiva LBD, Goldbeck R, Santos WDD, Squina FM. Ferulic acid and derivatives: molecules with potential application in the pharmaceutical field. Brazilian Journal of Pharmaceutical Science, 2013; 49(3): 395-411.

Sabina EP, Chandel S, Rasool MK. Evaluation of analgesic, antipyretic and ulcerogenic effect of Withaferin A. International Journal of Integrative Biology, 2009; 6 (2): 52-56.

Sarker SD, Bartholomew B, Nash RJ. Alkaloids from Balanites aegyptiaca. Fitoterapia, 2000; 71, 328-330.

Seo WG, Pae HO, Oh GS, Chai KH, Kwon TA, Yun YG, Kim NY, Chung HT. Inhibitory effect of methanol extract of Cyperus rotundus rhizomes on nitric oxide and superoxide productions by murine macrophage cell line, RAW 264.7 cells. Journal of Ethnopharmacology, 2001, 76: 59-64.

Singh N, Kulshrestha VK, Gupta MB, Bhargava KP. A pharmacological study of Cyperus rotundus. Indian Journal of Medicinal Research, 1970; 58: 103-109.

Sonwa MM, König WA. "Chemical study of the essential oil of Cyperus rotundus". Phytochemistry, 2001; 58(5): 799-810.

Sultana R. Ferulic acid ethyl ester as a potential therapy in neurodegenerative disorders. Biochim Biophysics Acta, 2012; 1822(5): 748-752.

Tawata S, Taira S, Kobamoto N, Zhu J, Ishihara M, Toyama S. Synthesis and antifungal activity of cinnamic acid esters Bioscience, Biotechnology, and Biochemistry 1996; 60: 909-910.

Thebtaranonth C, Thebtaranonth Y, Wanauppathamkul S, Yuthavong Y. "Anti-malarial sesquiterpenes from tubers of Cyperus rotundus: structure of 10, 12-peroxyca-lamenene, a sesquiterpene endoperoxide". Phytochemistry, 1995; 40: 125-128.

Uddin SJ, Mondal K, Shilpi JA, Rahnan MT. Anti-diarrheal activity of Cyperus rotundus. Fitoterapia, 2006; 77 (2): 134-136.

Vedavathy S, Rao KN. Antipyretic activity of six indigenous medicinal plants of Tirumala hills. India Journal of Ethnopharmacology, 1990, 33:193-196.

Venkatsubramanian P, Kumar K. S, Nair VSN. Cyperus rotundus, a substitute for Aconitum heterophyllum: studies on the Ayurvedic concept of Abhava Pratinidhi Dravya (drug substitution) Journal of Ayurveda and Integrative Medicine. 2010; 1(1): 33-39.

Weitzmann SA, Gordan LI. Inflammation and Cancer, role of phagocyte generated oxidants in carcinogenesis. Blood, 1990, 76(4): 655-663.

Wigdor S, Wilcox GL. Central and systemic morphine-induced antinociception in mice: Contribution of descending serotonergic and noradrenergic pathways. Journal of Pharmacology and Experimental Therapeutics, 1987; 242: 90 - 95.

Winter CA, Risely EA, Nuss GW. Proceedings of the Society for Experimental Biology and Medicine, 1962; 111: 544-547.

Wu P.-L., Wu T.-S., He C.-X., Su C.-H., Lee K.-H., Constituents from the stems of Hibiscus taiwanensis. Chemical Pharmaceutical Bulletin, 2005; 53: 56 - 59.

Yu J, Lei G, Cai L, Zou Y. Chemical composition of $C$. rotundus extract. Phytochemistry, 2004; 65: 881-889.

Zakaria ZA, Abdul Gani ZDF. Antinociceptive, antiinflammatory, and antipyretic properties of an aqueous extract of Dicranopteris linearis leaves in experimental animal models. Journal of Natural Medicines, 2008; 62: 179-187.

\section{How to cite this article:}

Manivannan R, Aeganathan R. Analgesic and anti-inflammatory activity of the extracts from Cyperus rotundus Linn rhizomes. J App Pharm Sci, 2016; 6 (09): 197-203. 